\title{
Income distribution peculiarities in differently developed selected European countries versus $Q$ atar
}

\author{
Manuela Tvaronavičienè \\ Department of Business Technologies and Entrepreneurship, \\ Vilnius Gediminas Technical University, \\ Lithuania \\ manuela.tvaronaviciene@vgtu.lt
}

\begin{abstract}
Development patterns of any country are determined by a wide array of factors. Those factors differ in developed and less developed countries. Developed countries, as a rule, rely on human resources, while less developed countries build their wellbeing on available natural resources. Anyway, income distribution across society of any country is an important constituent of entrepreneurship competitive potential. If the middle class prevails in a society, a consumption and saving model is to be expected, and if, on the contrary, lower or upper class dominates, the prevailing lifestyle and consumption patterns will be different. Successful entrepreneurship, which is the precondition of competitiveness of any country, requires clear understanding what income distribution patterns are characteristic for different countries and how these distribution changes are reacting to external factors, such as macroeconomic cycles in partnering countries or political climate, Trumps' policy, Brexit scenarios, Eurozone or global crises etc. The presented here study will be based on the comparison of distribution patterns of income and wealth in developed European countries, which would be represented by Germany, then in comparatively less developed European countries, which would be represented by Lithuania and Romania, and also in Qatar. After juxtaposing of income distribution patterns and generalizations, sensitivity of income distribution across society to external factors, listed above, will be checked. For that purpose, a modelling tool provided by the Passport database owned by the Euromonitor International Company will be used. This modelling tool is available for official subscribers of the Passport. The obtained results reveal income distribution patterns and resilience of the selected countries to external factors. The results have both theoretical and practical value since consistent patterns of income and wealth distribution are revealed.
\end{abstract}

Keywords: development patterns, income distribution, European countries, Qatar, consumption patterns.

JEL Classification: E21 


\section{INTRODUCTION}

Regional development issues do not lose their topicality over time and therefore remain in the focus of both scientists and politicians (Simionescu, 2016; Androniceanu et al., 2018; Miłek, 2018; Zeibote et al. 2019; Eddelani et al., 2019; Lavrinenko et al., 2019; Horská et al., 2019; Draskovic et al., 2019).

Development patterns of any country are determined by viability and competitiveness of its business companies. Success of any business company, in its turn, is determined by the conditions of doing business and the ability of organization to manage its internal resources, first of all, human, capital resources or knowledge. Elaboration of fruitful strategies is not an easy task. External business environment inevitably affects performance of any business company, and this impact not necessarily can be tangible. There is a whole strand of literature dedicated to elaboration of a wide array of business environment facets. A separate discussion can be triggered about composing a system of indicators which would reflect the complexity of business environment for business doing (Rogalska, 2018; Bilan et al, 2017). Not aiming to embrace all the system of factors, let us just mention some constituents of business environment, which are tackled by the latest scientific literature. The following examples could be provided: business cycle (Bikas \& Saponaite, 2018; Filipishyna et al. 2018; Luchko, Arzamasova \& Vovk, 2019; Tvaronavičienė, 2018); economic policy (Veselovsky et al., 2018), attitudes to entrepreneurs on the side of the state and society, affecting the propensity to start business (Ključnikov et al., 2016; Naushad et al., 2018; Zajkowski \& Domańska, 2019; Dvorský et al., 2019); health of banking system; availability, composition and quality of labour force (Sagiyeva et al., 2018; Prakash, Garg, 2019), accounting system, adopted in a particular country (Vegera et al., 2018; Hilkevics \& Semakina, 2019) etc. The list could be continued, of course. In the presented paper we will focus on income distribution patterns, which as well are the constituents of business environment and thus should be taken into account by both start-ups and mature business companies if they are considering strategies on further development (Androniceanu \& Beșciu, 2017; Tvaronavičiené \& Gatautis, 2017; Pauhofova et al., 2018; Mishchuk at al., 2018).

The presented paper aims to elaborate the income distribution patterns in four different countries: Germany, Romania, Lithuania and Qatar. The indicated countries have been chosen with a purpose to examine a range of differences in societies' structure measured in terms of purchasing power. Germany here represents well developed European countries, Romania and Lithuania -- comparatively less developed European countries, and Qatar represents strategic energetic resources exporting country (liquid gas in the first place). Besides comparison of income distribution peculiarities in the selected countries, we will check the sensitivity of income distribution patterns to some external shocks, such as Trump's policy and one of the Brexit scenarios which seems to be most probable right now (this aspect will be elaborated below).

Evaluation of income distribution patterns will be based on the assumption that availability of middle class in any society is a feature of healthy business environment or, putting it in another way, healthy entrepreneurship ecosystem. The middle class, as we see it, is a driver of business development, since it consumes the whole spectrum of basic goods and services; while lower class obviously suffers from constraints and is forced to restrict consumption, even of the basics; upper class, on the opposite, is a major consumer of luxury goods, which are always a niche production. Thus, the latter do not really contribute that substantially to economic development, if juxtaposed to regular products and services devised for middle-class consumers.

\section{AIM, METHODS AND DATA}

The aim of presented paper is to shed a light on differences on income distribution, in European countries of slightly different development versus natural resources abundant country, such as Qatar. The 
obtained results will what provide opportunities for businesses to articulate their strategies via targeting clearly set goals, and ultimately increase their competitiveness.

We base our methodology on the on the following approach: income distribution patters are affected by the following factors. The first, an approach towards what range of income is perceived as representing middle class; the second, pattern of economic development under different external conditions. The provided methodology is implemented by forecasting and modelling methods. Specifically, for analysis of income distribution patterns modeling tool provided by Passport database owned by Euromonitor International Company will be used. The modelling tool is available for official subscribers of the Passport. Income distribution structure, how we see it, depends on what income range we treat as characteristics of middle class of society. Here we do not introduce unconventional approaches and therefore will employ segmentation suggested the modeling tool; i.e. we accept approach, which assumes that middle class of any country is a segment of population with annual disposable income between 10 thousand and 30 thousand USD.

\section{RESULTS AND DISCUSSION}

Application of modelling tool, provided by Passport allowed to reveal us the differing income distribution patterns in the considered countries, see Figure 1, provided below.

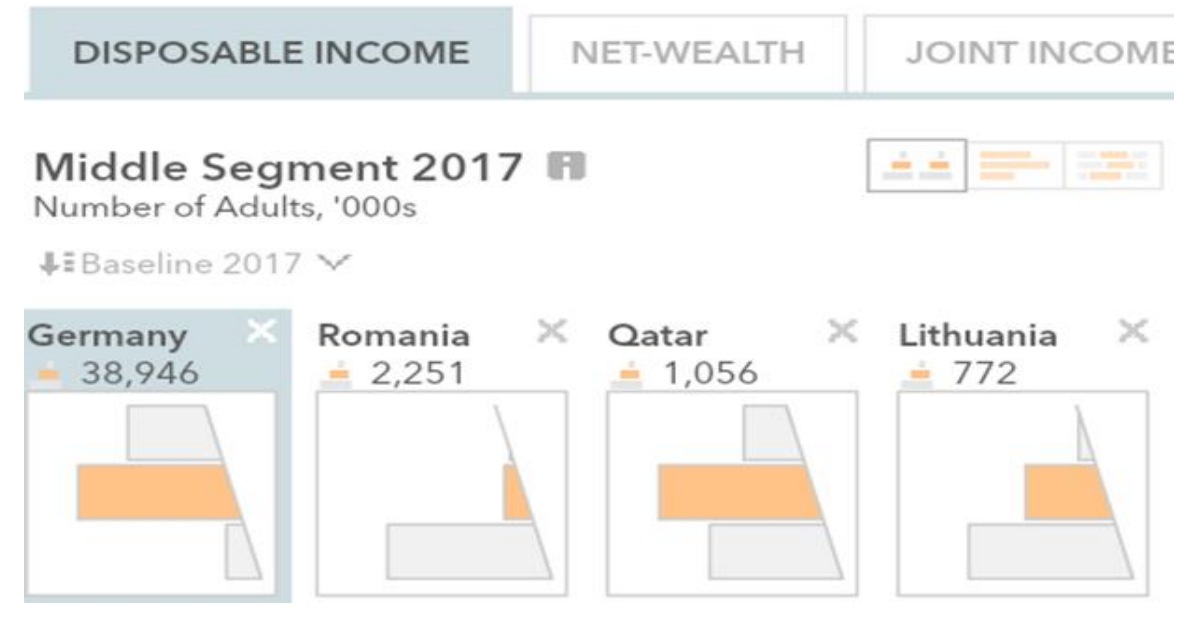

Figure 1. Income distribution across societies of Germany, Romania, Qatar and Lithuania Source: Passport modeling tool, powered by Euromonitor International, usage is licensed

The obtained results reveal that four selected countries belong to three different types of income distribution. Germany, which represent well developed European countries has the biggest share of population attributed to middle class. The top class is significant in Germany's society, and what is the most importance, the bottom class is comparatively small. That pattern of distribution disposable income across society could be treated as desirable target for economic politicians.

Romania and Lithuania belongs to group of European countries, which are slightly less developed. Their income distribution patterns are rather similar: majority of society's members appears in the bottom slice of society with disposable yearly income less than 10 thousand USD. The higher the disposable income, the smaller number of inhabitants can enjoy it. That tendency is valid for both less developed European countries, Romania and Lithuania. Here we can claim that certain consistent patterns of income distribution are revealed for European countries with differing level of development, at least. Here we need to mention, 
that income distribution patterns were tested almost for all better developed and less developed European countries additionally. We do not present here illustrating income distribution charts for one reason: the results obtained are consistent completely with insights formulated above and therefore verify insight about existence of consistent patterns in income distribution in better developed and less developed European countries.

Let us focus on the fourth country, selected for this comparison. It is obvious from income distribution chart provided in Figure 1 that this country differs completely from European countries: here middle class of society dominates what resemble Germany, if to take account just middle class prevalence. Further, if estimating share of the top class in Qatar, the situation resembles Germany, in a sense that upper class is existent, its share in a whole society is significant, and it is smaller than a middle class. The essential difference of income distribution pattern among Germany and Qatar lies in share of bottom class. If in Germany bottom class represents minor part of society, in Qatar this part of society is significant.

Here we are not going into reasons of one or another income distribution patterns, which are determined by historical development, availability of natural resources, industry and international trade structure and many more factors.

Some economic facts about Qatar, which are provided by database Passport: "Qatar has the world's third largest reserves of natural gas. The country's oil and gas industries employ the greater part of the active workforce, accounting for more than $80 \%$ of export revenues and $50 \%$ of GDP. The manufacturing sector accounts for $8.2 \%$ of GDP and employs $6.7 \%$ of the workforce. The service sector represents $52.4 \%$ of GDP. Boosted by higher world energy prices and increasing production of natural gas, Qatar's economy grew at an exceptionally rapid pace during the past decade. Qatar is currently the world's largest LNG exporter. The current account surplus amounted to $3.8 \%$ of GDP in 2017 and it will widen to $6.0 \%$ of GDP in 2018“ (Passport). Thus, we see, that Qatar have no issues related to energy security issues, which currently are one of the most urgent issues in European countries (Abrhám et al. 2018; Tvaronavičiené et al. 2017; 2018). We do not tackle energy security and energy efficiency issues in this paper; indicated above remark just draws attention to the differences in development drivers of considered countries.

\section{FORECASTED INCOME DISTRIBUTION PATTERNS IN CASE OF DIFFERENT GLOBAL SCENARIOS}

Let us examine how number of citizens attributed to the middle class will change in the considered countries until year 2022. We will juxtapose several scenarios: one scenario will be under ceteris paribus conditions, and another two will take into account the several probable global risks, which will be indicated below.

Below there are presented forecasts of middle class change in case of ceteris paribus scenario for our considered countries (Figure 2 and Figure 3). 

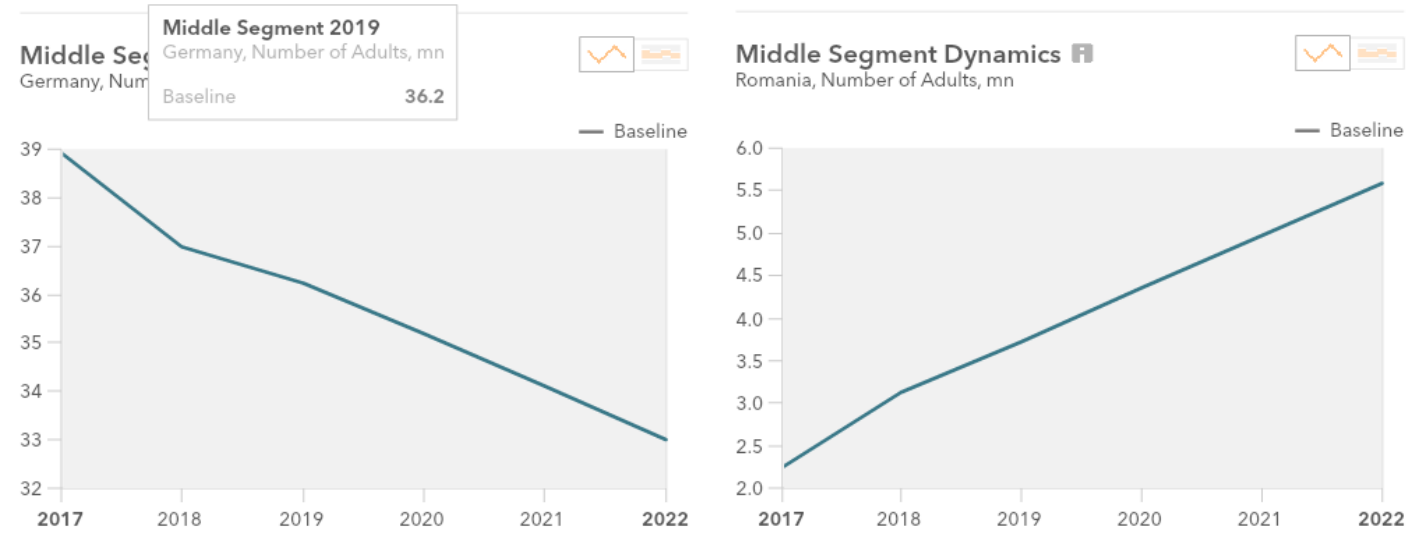

Figure 2. Middle class change in Germany (on the left) and Romania (on the right), ceteris paribus scenario

Source: Passport modelling tool

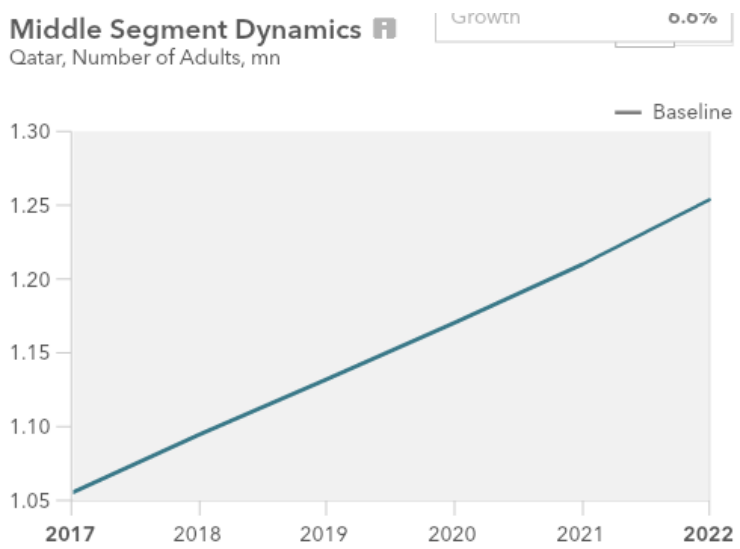

Middle Segment Dynamics Fi Lithuania, Number of Adults, mn

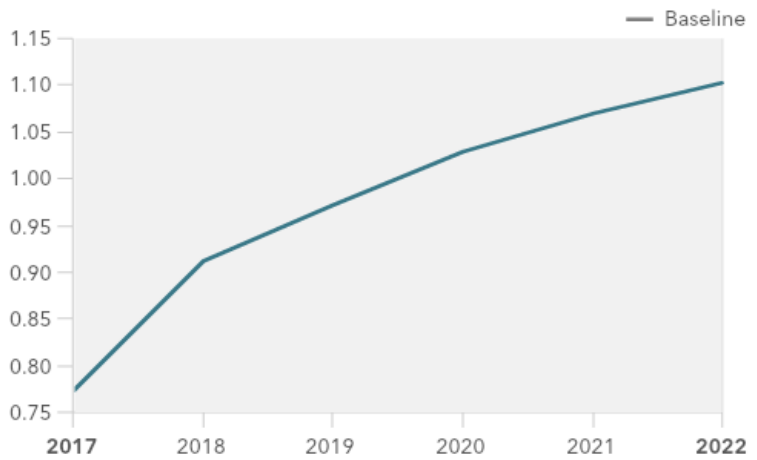

Figure 3. Middle class change in Qatar (on the left) and Lithuania (on the right), ceteris paribus scenario

Source: Passport modelling tool

The forecasted data indicate that the middle class will grow, if estimated in number of people belonging to this class, in three countries out of four our considered countries: in Romania, Lithuania and Qatar. Meanwhile, in Germany number of adults belonging to this class will diminish.

Let us examine sensitivity of income distribution pattern of Qatar to one of global threats, specifically Eurozone recession (Figure 4). Qatar is remoted from European countries geographically; there are no close economic relations. Anyway, Eurozone recession would retard increase in numbers of middle class. This effect, most likely, would be determined by diminishing capacity of purchasing power of European countries, which are consumers of energetic resources. 

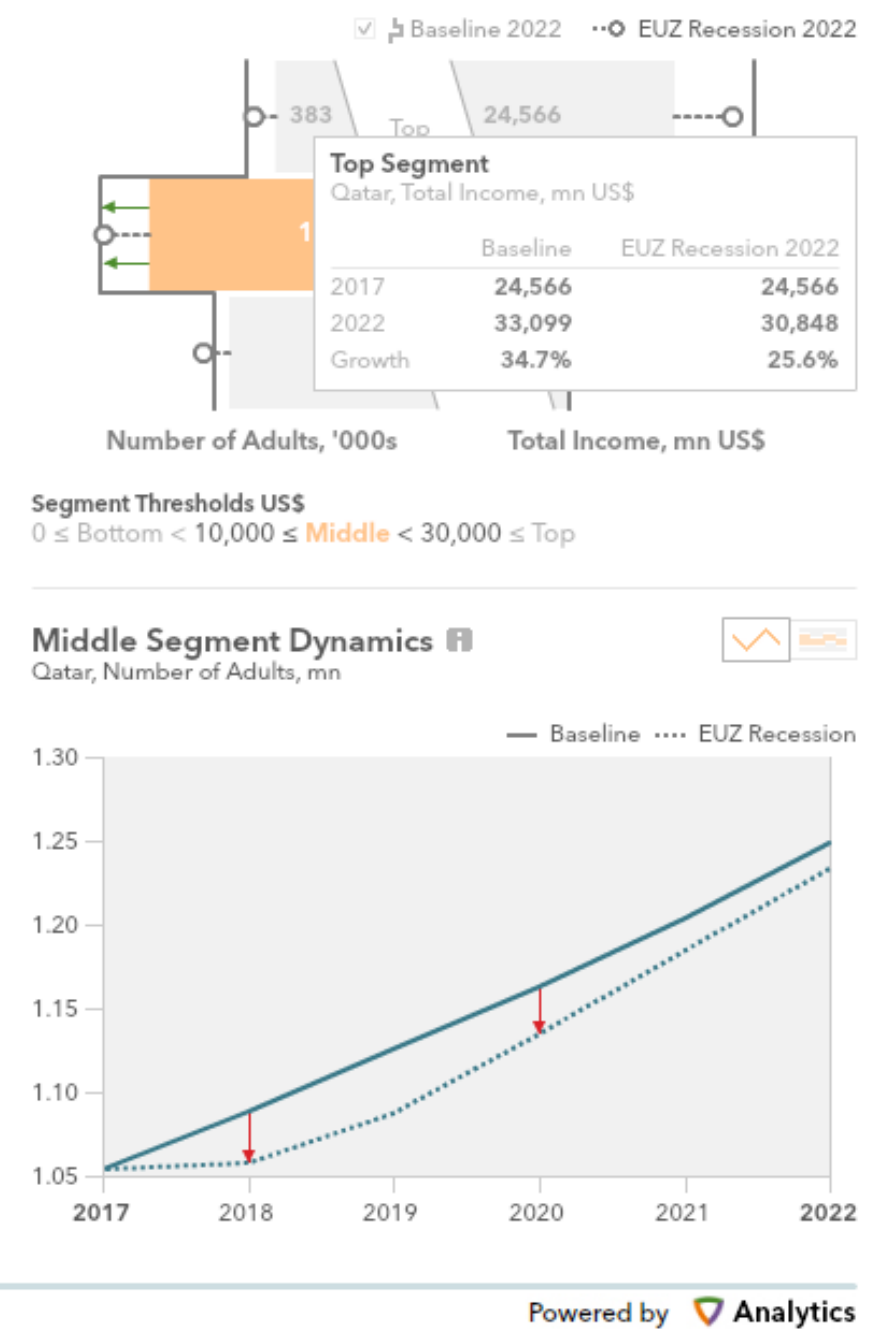

Figure 4. Sensitivity of Qatar to Eurozone Recession (scenario probability 7 \%)

Source: Passport modelling tool

We checked sensitivity for income distribution pattern to other global threats. A global theat with the estimated highest probability, which is expected to be $30 \%$, so called "No-deal Brexit scenario" as it appeared, almost has no impact on distribution pattern of income of any of our considered country. Brexit scenarios, as it appears, being widely discussed, actually, most likely, will affect just economy of UK itself (Tvaronavičienè, 2018).

Other threats, distinguished by this reputable database, such as "Trade war" with probability of $15 \%$, "China hard landing" with probability of $9 \%$ etc. do not have any more palpable impact on our considered phenomenon. Besides Eurozone crisis scenario, only another, rather similar scenario of wider range, specifically "Global crisis" with probability of $30 \%$ would rather similarly would shift down tendency of increase of middle class in Qatar.

To generalize, there are rather specific income distribution patterns in considered four countries, which are attributed to three different categories: the better developed European countries, the less developed European countries, and energy abundant Middle East country. Those income distribution patters are not that sensitive to contemporary global threats. The comparative insensitivity of income distribution patterns to global factors allows business companies to predict more easily consumption patterns of those countries, 
which inevitably stem from historically recorded data. Below there are provided historical and forecasted consumption patterns for two (out of four) considered countries, specifically Qatar and Lithuania, respectively Figure 5 and Figure 6, presented below.

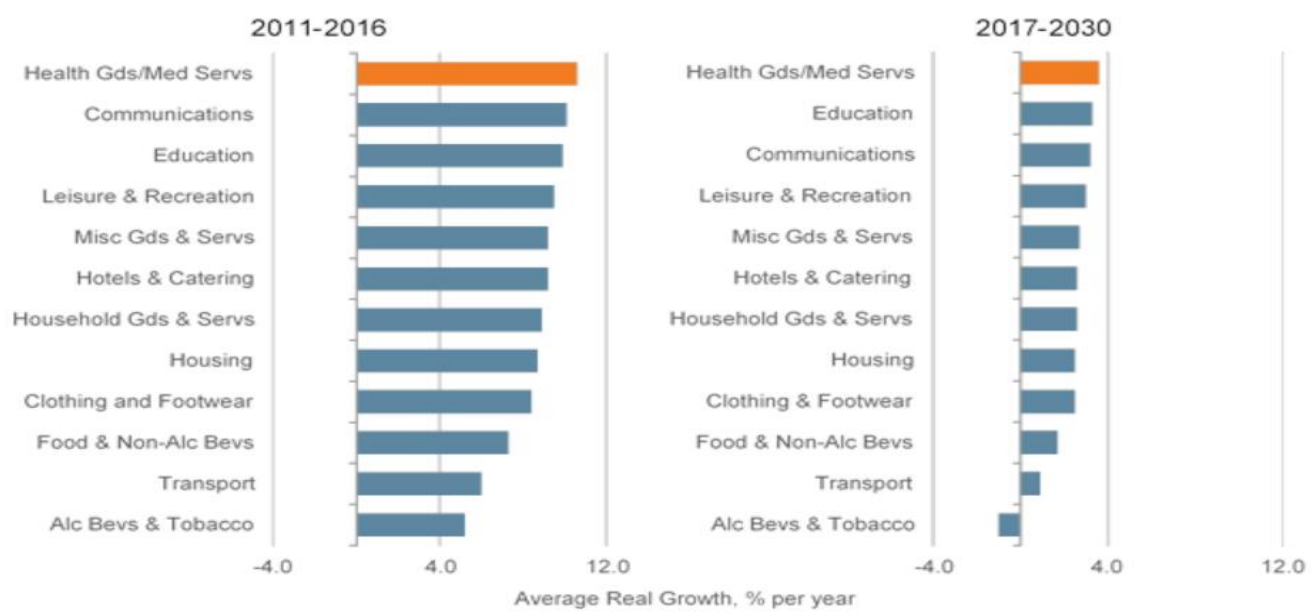

Figure 5. Historical (years 2011-2016) and forecasted (years 2017-2030) consumption patterns in Qatar

Source: Passport, consumer expenditure average annual real growth by category 2011-2030

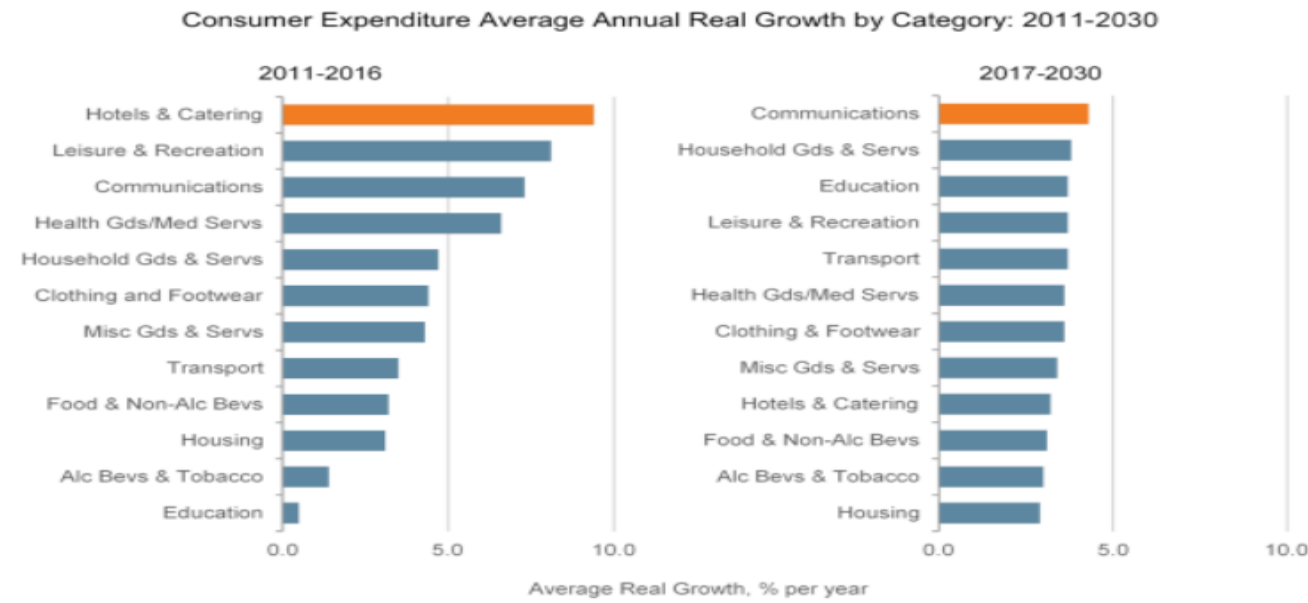

Figure 6. Historical (years 2011-2016) and forecasted (years 2017-2030) consumption patterns in

\section{Lithuania}

Source: Passport, consumer expenditure average annual real growth by category 2011-2030

Comparison of consumption patterns of two small countries with different income distribution patterns across society allows to reveal priorities of consumers. In the society, where middle and top class prevails, the first there areas, which collect majority of money spent are: health goods and medical services, communication and education. Long run forecasting (until year 2030) suggests that education would become the second priority, on which money will be spent, and, ultimately, the same three main areas will be listed in the following order: health goods and medical services, education and communication (data obtained for Qatar, Figure 5). 
It is peculiar, that historical and forecasted data for Lithuania, which has no top class, comparatively small middle class and significant bottom class, spending patterns completely differ from the case described above: three major spending priorities, historically, are hotels and catering, leisure and recreation, and communication. In the long run (forecasted until year 2030), the priorities will be communication, household goods and services, and education. Let us recall that Lithuania's middle class would grow, as indicated in Figure 3. This growth will push spending on communication and educations, which are categories of spending characteristic for our considered society with prevailing middle and top class. The main difference, as we see, is spending attitude to health goods and medical services: the spending on that category, which historically occupied the fourth position will drop to the $6^{\text {th }}$ position in long run. The tendency is rather negative, unless data available for forecasting were distorted by "shadow economy in this sector", which in this case would cause research limitations.

\section{CONCLUSION}

The aim of this article was to reveal differences in income distribution, in selected European countries and Qatar. The obtained results allow us to claim that the best developed European countries during the neared 10 years would display diminishing of the layer of society, which we attributed to the "middle class". Let us recall that is was assumed that the middle class represents households with income between 10 and 20 thousand Euros per annum. Most likely, in well-developed European countries this segment will diminish due to considerable raise in income per capita. We assume, that overall increase in income would mean that the current "middle class" will be considered as "lower class", which will contract. As concerns income distribution of comparatively less developed European countries and Qatar, income distribution patterns appear to be rather similar, a conclusion, which is rather unexpected, especially taking into account wide range of differences of those countries. Alas, the results allow us to notice some convergence of development patterns in the area of income distribution, i.e. gradual expansion on the middle class. We can claim, that the growing purchasing capacity of those countries would contribute to their economic viability, and therefore increase of competitiveness. The consumption patterns, as we see (specifically, shift towards spending on education and communication) signal about similarities of development directions brought in by converging middle class development patterns.

To generalize, sustainable development of entrepreneurial companies could be facilitated by enhancing awareness of entrepreneurs about purchasing capacity in various countries, tendencies of change of this capacity and resilience of existing consistent patterns of income distribution to external impacts. This information would facilitate more successful targeting specific market segments through better understanding of lifestyles and specific needs of potential clients. The obtained results allowed us to reveal consistent patterns of distribution income across of different countries. As well tendencies of middle class change were provided, sensitivity of income distribution patterns to global threats provided and interpreted, spending patterns forecasted.

\section{LIMITATIONS OF THE RESEARCH AND FURTHER ELABORATIONS}

Each research has got its limitation. In this paper we assume that middle class is within income limits of 10 and 30 thousand USD. If we use any other income range we will receive slightly different income distribution patterns. Therefore this is already research limitation. All forecasts are credible as far ceteris paribus assumption is maintained. This assumption could be maintained in ideal world, which, actually, does not exist. Therefore all forecasts and modellings usually are more credible for short-term periods, alas, not for long-terms, as we aim. In order to have more credible picture of long-term forecast and modelling, those 
attempts have to be repeated and deviations recorded, analyzed and interpreted. Therefore, this research could and have to be continued, other assumptions, formulated and verified.

\section{REFERENCES}

Abrhám, J., Britchenko, I., Jankovic, M., \& Garškaitè-Milvydienė, K. (2018). Energy security issues in contemporary Europe. Journal of Security and Sustainability Issues, 7(3), 387-398. doi:https://doi.org/10.9770/jssi.2018.7.3(1)

Androniceanu, A., \& Beșciu, C. D. (2017). The link between social inequalities, health' system characteristics and R\&D expenditure-worldwide evidence, Romanian Statistical Review, (2), 21-41.

Androniceanu, A., Georgescu, I.A., \& Pegulescu, A. (2018).Essential Competitive Advantages for a Sustainable Economic Development - Case of Romania, Proceedings of the 31st International Business Information Management Association Conference (IBIMA), 25-26 April 2018, Milan, Italy, Innovation Management and Education Excellence through Vision 2020, Editor Khalid S. Soliman, International Business Information Management Association (IBIMA), ISBN: 978-0-9998551-0-2, 1853-1861.

Bikas, E., \& Saponaite, V. (2018). Behavior of the Lithuanian investors at the period of economic growth. Entrepreneurship and Sustainability Issues, 6(1), 44-59. doi:https://doi.org/10.9770/jesi.2018.6.1(4)

Bilan, Y., Nitsenko, V., Ushkarenko, I., Chmut, A., \& Sharapa, O. (2017). Outsourcing in international economic relations. Montenegrin Journal of Economics, 13(3), 175-185.

Draskovic, V., Draskovic, M. \& Bilan, S. (2019). Motivation, Methodology, and Phenomenology of Institutional Nihilism in the SEE Countries. Montenegrin Journal of Economics, 15(2), 7-14. doi 10.14254/1800-5845/2019.152.1

Dvorský, J., Petráková, Z., Zapletalíková, E., \& Rózsa, Z. (2019). Entrepreneurial propensity index of university students. The case study from the Czech Republic, Slovakia and Poland. Oeconomia Copernicana, 10(1), 173-192. doi: https://doi.org/10.24136/oc.2019.009

Eddelani, O., El Amrani El Idrissi, N., \& Monni, S. (2019). Territorialized forms of production in Morocco: provisional assessment for an own model in gestation. Insights into Regional Development, 1(1), 6-18. doi:http://doi.org/10.9770/IRD.2019.1.1(1)

Filipishyna, L., Bessonova, S., \& Venckeviciute, G. (2018). Integral assessment of Developmental stability: cases of Lithuania and Ukraine. Entrepreneurship and Sustainability Issues, 6(1), 87-99. doi:http://doi.org/10.9770/jesi.2018.6.1(7)

Hilkevics, S., \& Semakina, V. (2019). The classification and comparison of business ratios analysis methods. Insights into Regional Development, 1(1), 48-57. doi:http://doi.org/10.9770/IRD.2019.1.1(4)

Horská, E., Moroz, S., Poláková, Z., Nagyová, L’udmila, \& Paska, I. (2019). Evaluation of interaction between chosen indicators of development of regions in Ukraine. Equilibrium. Quarterly Journal of Economics and Economic Policy, 14(2), 341-357. doi: https://doi.org/10.24136/eq.2019.016

Ključnikov, A., Belás, J., Kozubíková, L., \& Paseková, P. (2016). The Entrepreneurial Perception of SME Business Environment Quality in the Czech Republic. Journal of Competitiveness, 8(1), 66-78. doi: 10.7441/joc.2016.01.05

Lavrinenko, O., Ignatjeva, S., Ohotina, A., Rybalkin, O., \& Lazdans, D. (2019). The Role of Green Economy in Sustainable Development (Case Study: The EU States). Entrepreneurship and Sustainability Issues, 6(3), 1013-1026. doi:http://doi.org/10.9770/jesi.2019.6.3(4)

Luchko, M., Arzamasova, O., \& Vovk, I. (2019). Personnel potential of national economy and gross domestic product: The case of Ukraine. Montenegrin Journal of Economics, 15(2), 59-70.

Mishchuk, H., Samoliuk, N., Bilan, Y., \& Streimikiene, D. (2018). Income inequality and its consequences within the framework of social justice. Problemy Ekorozwoju, 13(2), 7(2), 27-43

Naushad, M., Faridi, M. R., \& Syed, A. M. (2018). Economic development of community by entrepreneurship: an investigation of the entrepreneurial intent and the institutional support to the local community in Al-Kharj region. Entrepreneurship and Sustainability Issues, 5(4), 899-913. doi:https://doi.org/10.9770/jesi.2018.5.4(14)

Miłek, D. (2018). Spatial differentiation in the social and economic development level in Poland. Equilibrium. Quarterly Journal of Economics and Economic Policy, 13(3), 487-507. doi: https://doi.org/10.24136/eq.2018.024

Passport. https://www.portal.euromonitor.com/portal/magazine/homemain 
Pauhofova, I., Stehlikova, B, Kljucnikov, A., \& Androniceanu, A. (2018). Spatial and sectoral conditionality of the average monthly nominal wage in the Slovak Republic. Transformations in Business \& Economics, 17(3), 155-168.

Prakash, R., \& Garg, P. (2019). Comparative assessment of HDI with Composite Development Index (CDI). Insights into Regional Development, 1(1), 58-74. doi:http://doi.org/10.9770/IRD.2019.1.1(5)

Rogalska, E. (2018). Multiple-criteria analysis of regional entrepreneurship conditions in Poland. Equilibrium. Quarterly Journal of Economics and Economic Policy, 13(4), 707-723. doi: https://doi.org/10.24136/eq.2018.034

Sagiyeva, R., Zhuparova, A., Ruzanov, R., Doszhan, R., Askerov, A. (2018). Intellectual input of development by knowledge-based economy: problems of measuring in countries with developing markets. Entrepreneurship and Sustainability Issues, 6(2), 711-728. doi:https://doi.org/10.9770/jesi.2018.6.2(17)

Simionescu, M. (2016). Competitiveness and economic growth in Romanian regions. Journal of Competitiveness, 8(4), pp. 46-60. doi: 10.7441/joc.2016.04.03

Tvaronavičiené, M., Mentel, G., \& Chyrva, H. (2018). Leadership in Energy Security: Behavioral Patterns and LongTerm Energy Intensity. In: Strielkowski W., Chigisheva O. (eds) Leadership for the Future Sustainable Development of Business and Education. Springer Proceedings in Business and Economics. Springer, Cham https://doi.org/10.1007/978-3-319-74216-8_59doi:https://link.springer.com/chapter/10.1007\%2F978-3319-74216-8_59\#citeas

Tvaronavičienè, M. (2018). Preconditions of sustainable entrepreneurship: Estimating of Brexit scenarios' impact on macroeconomic environment. Polish Journal of Management Studies, 17(2), 222-234 doi:https://doi.org/10.17512/pjms.2018.17.2.19

Tvaronavičienė, M., Nesterova, K., \& Kováčik, V. (2017). Energy security and long-term energy efficiency: case of selected counties. Journal of Security and Sustainability Issues, 7(2), 349357. doi:https://doi.org/10.9770/jssi.2017.7.2(14)

Tvaronavičienè, M., \& Gatautis, R. (2017). Peculiarities of income distribution in selected countries. Economics and Sociology, 10(4), 113-123. doi:https://doi.org/10.14254/2071-789X.2017/10-4/9

Vegera, S., Malei, A., \& Trubovich, R. (2018). Accounting development of natural resources in organizations carrying out the disposal of municipal waste and biogas extraction in the context of the "green" economy. Entrepreneurship and Sustainability Issues, 6(1), 211-225. doi:http://doi.org/10.9770/jesi.2018.6.1(14)

Veselovsky, M. Y., Pogodina, T. V., Ilyukhina, R. V., Sigunova, T. A., \& Kuzovleva, N. F. (2018). Financial and economic mechanisms of promoting innovative activity in the context of the digital economy formation. Entrepreneurship and Sustainability Issues, 5(3), 672-681. doi:https://doi.org/10.9770/jesi.2018.5.3(19)

Zeibote, Z., Volkova ${ }_{s}$ T., \& Todorov, K. (2019). The impact of globalization on regional development and competitiveness: cases of selected regions. Insights into Regional Development, 1(1), 33-47. doi: http://doi.org/10.9770/IRD.2019.1.1(3)

Zajkowski, R., \& Domańska, A. (2019). Differences in perception of regional pro-entrepreneurial policy: does obtaining support change a prospect?. Oeconomia Copernicana, 10(2), 359-384. doi: https://doi.org/10.24136/oc.2019.018 